
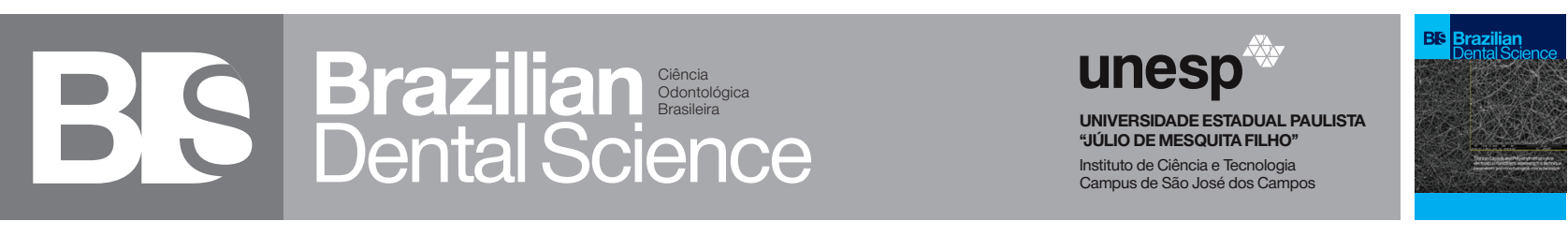

\title{
Water sorption and solubility of a nanofilled composite resin protected against erosive challenges
}

Sorção de água e solubilidade de uma resina composta nanoparticulada protegida contra desafios erosivos.

Katharina Maciel Ferreira Villaça MAIA ${ }^{1}$, Felipe Vilasboas RODRIGUES ${ }^{1}$, Janaina Emanuela DAMASCENO ${ }^{1}$, Rodrigo Vitória da Costa RAMOS $^{2}$, Vivian Leite MARTINS ${ }^{1}$, Max José Pimenta LIMA ${ }^{3}$, Andrea Nóbrega CAVALCANTI ${ }^{1,2}$

1 - Dentistry Course, School of Medicine and Public Health of Bahia (BAHIANA) - Salvador, BA - Brazil.

2 - School of Dentistry, Federal University of Bahia (FOUFBA) - Salvador, BA - Brazil.

3 - Institute of Health Sciences - Federal University of Bahia (UFBA) - Salvador, BA - Brazil.

\section{ABSTRACT}

Objective: Erosive challenges are capable of demineralizing dentin and promote physical and mechanical changes in restorative materials. The present study investigates the water sorption and solubility of one nanofilled composite resin submitted to erosive challenges. It also studies procedures that can protect these surfaces. Material and Methods: 120 specimens were used. It was divided into four experimental groups according to the type of surface protection used (negative control, topical application of fluoride, resin-modified glass ionomer varnish and resin-based sealant). Subsequently, they were randomly assigned to three subgroups $(\mathrm{n}=10)$, (negative control, 9 and 18 cycles of DES-RE). According to the exposure to the simulated solution of gastric acid (DES) $(5 \% \mathrm{HCl}, \mathrm{pH}$ $=2.2$ ) and subsequent remineralization (RE). The specimens were dehydrated until a constant mass was obtained and immersed in deionized water for 7 days, when they were weighed and submitted to a new dehydration. The values of water sorption and solubility were calculated according to the ISO 4049:2000 specifications and analyzed statistically (2-way ANOVA / Tukey, alpha = 5\%). Results: The water sorption and solubility averages after 18 cycles of DES-RE were statistically higher than negative control. Independently of the erosive challenge received, the specimens protected with the resin-modified glass ionomer varnish presented a significant increase in the values of loss and mass gain in relation to the other groups. Conclusion: No control method presented promising surface protection capacity of composite resin against to erosive challenges.

\section{KEYWORDS}

Tooth erosion; Dental restoration permanent; Solubility.

\section{RESUMO}

Objetivo: Os desafios erosivos capazes de desmineralizar o esmalte também podem promover alterações físicas e mecânicas nos materiais restauradores. $\mathrm{O}$ presente trabalho investigou a sorção de água e solubilidade de uma resina composta nanoparticulada submetida a desafios erosivos. Também estudou procedimentos que possam proteger estas superfícies. Material e Métodos: Foram confeccionados 120 corpos de prova. Foram divididos em quatro grupos experimentais, de acordo com o tipo de proteção superficial empregada (controle negativo, aplicação tópica de flúor, verniz de ionômero de vidro modificado por resina e selante resinoso). Após, foram aleatoriamente distribuídos em três subgrupos $(n=10)$ (controle negativo, 9 e 18 ciclos DES-RE). De acordo com a exposição à solução simulada de ácido gástrico (DES) (HCl a $5 \%, \mathrm{pH}=2,2$ ) e posterior remineralização (RE). Os espécimes foram desidratados até obtenção de massa constante e imersos em água destilada por 7 dias, quando foram pesados, e submetidos à nova desidratação. Os valores de sorção e solubilidade foram calculados de acordo as ISSO 4049:2000 e analisados estatisticamente (2-way ANOVA /Tukey, alfa $=5 \%$ ). Resultados: Independentemente do desafio erosivo recebido, os corpos de prova protegidos com o verniz de ionômero de vidro modificado por resina, apresentaram aumento significativo dos valores de perda e ganho de massa em relação aos demais grupos. Conclusão: Nenhum método de controle apresentou promissora capacidade de proteção superficial da resina composta frente aos desafios erosivos.

\section{PALAVRAS-CHAVE}

Erosão dentária; Restauração dentária permanente; Solubilidade. 


\section{INTRODUCTION}

D ental erosion has as etiological agent acids of different nature, which leads to the inorganic matrix demineralization of the tooth. [1] These acids might have endogenous origin (intrinsic erosion), commonly related to the gastric acid from reflux and other disorders. Alternatively, it may be exogenous (extrinsic erosion), usually associated with dietary components and environmental factors. However, the acids may have unknown origin (idiopathic erosion), when there is no conclusive diagnosis, even after anamnesis and / or clinical exams. [2].

Endogenous and exogenous acids are the mainly responsible for the increased incidence and prevalence of dental erosion. [3] However, the erosive potential prevenient from gastric acid may be more severe than exogenous acids due to its low $\mathrm{pH}$ and high frequency of dental contact in patients with gastroesophageal disorders. [3,4] In addition, gastric juice has a higher acidity, which leads to a severe erosion pattern. [5]

Intrinsic or extrinsic acids, beyond being able to demineralize dental structure, may also affect restorative materials present in the oral cavity. [2] Around composite resin, the acidic challenges can affect several aspects, among them, the physical and mechanical properties. [6]

Knowing the possible effects of dental erosion, some agents of dental protection and restorative materials have been studied. [7,8] Among them, the best known and used are fluoride compounds, which act in the remineralization of dental tissues. $[7,8]$ Although, it is believed that the most effective techniques are lacquers and surface sealants, capable of acting as a barrier to erosive injury. [1] Therefore, there is limited scientific evidence of the effect of such materials on the surface protection of restorative materials, aiming for a longer life for the technique.

Analysis of water sorption and solubility is an important tool to predict the clinical behavior of a material. Also more particularly, its stability in a humid environment such as the oral cavity. Water exposure may result in irreversible changes in composite resin, such as fissures, cracking and hydrolytic degradation of the matrix chemical components. $[9,10]$ Therefore, the present study proposes to investigate the dynamics the water sorption and solubility of a composite resin submitted to erosive challenges and protected with different materials. The experimental hypotheses is than there would be influence of the method of surface protection of the composite resin in the sorption of water and solubility in front of erosive challenges.

\section{MATERIAL AND METHODS}

\section{Sample preparation}

Initially, molds were made in addition silicone (Nova DFL, Taquara, RJ, Brazil) with internal diameter of $8 \mathrm{~mm}$ and $1 \mathrm{~mm}$ in depth. Each mold was used in the preparation of 30 samples. For the preparation of the 120 samples in composite resin (Filtek Z350 XT A3B; 3M ESPE, Sumaré, SP, Brazil), the material was inserted into the mold until it was completely filled. Then, a polyester strip followed by a glass plate was then placed on the sample. After $5 \mathrm{~s}$ of material accommodation, the glass plate was removed and the composite resin was photopolymerized with LED photoactivator a $1500 \mathrm{~mW} / \mathrm{cm}^{2}$ light intensity (Radii Plus; SDI, SP, Brazil) for 40s.

The samples were removed from the mold and finished with 400 mesh granulation sandpaper (Vonder - ODV, Feira de Santana, BA, Brazil) for edges regularization. Individually they were inserted into light-free Eppendorf closed, preventing any interference during the experiment, and stored in an incubator (Quimis, Diadema, SP, Brazil) at $37^{\circ} \mathrm{C}$ without humidity.

\section{Samples Surface protection}

Randomly, the samples were numbered and distributed in four control groups $(\mathrm{n}=10)$ to the posterior erosive challenge. (Figure 1) 


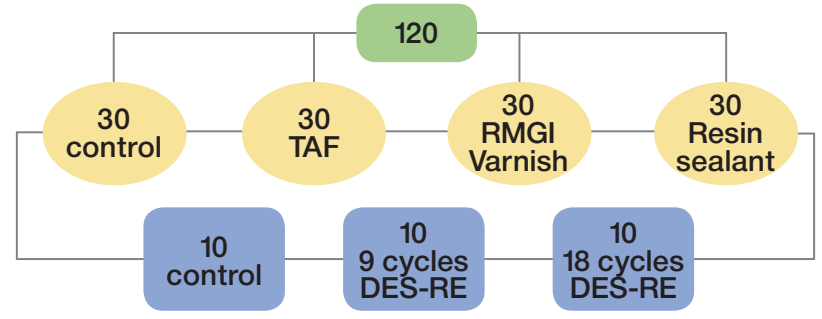

Figure 1 - Division of experimental groups.

- Negative Control: the samples were not submitted to any form of erosion control, only being kept without humidity at $37^{\circ} \mathrm{C}$ for $24 \mathrm{~h}$.

- Topical Application of Fluoride (TAF): the samples were immersed in $30 \mathrm{ml}$ of neutral NaF gel (Nova DFL, Taquara, RJ, Brazil) for 1 min. Afterwards, washed thoroughly with water for 10 s to remove the gel excesses, and also, washed in $30 \mathrm{ml}$ of deionized water for $4 \mathrm{~min}$ in an ultrasonic washer (UNIQUE Industria e Comércio LTDA, São Paulo, SP, Brazil). Finally, they were dried with absorbent paper and returned to individual storage at $37^{\circ} \mathrm{C}$ without humidity for $24 \mathrm{~h}$.

- Resin-modified glass ionomer varnish (RMGI Varnish): product (Clinpro XT Varnish, 3M ESPE, St Paul, MN, USA). Initially, the all surfaces were conditioned with $37 \%$ phosphoric acid (Biodynamic Chemistry and Farm LTDA, Ibiporã, PR, Brazil) for 15s. After that they were washed with water for 30s, and then dried with absorbent paper. The two pastes of the ionomer, base and catalyst, were dispensed equally in a place, and manipulated for $15 \mathrm{~s}$. Subsequently a thin layer of the product was applied on all sample surfaces, and photoactivated for 20 s. After, stored at $37^{\circ} \mathrm{C}$ without humidity for $24 \mathrm{~h}$.

- Resin Sealant: product (Fortify, Bisco, Schaumburg, USA), the all surfaces were conditioned with $37 \%$ phosphoric acid for $15 \mathrm{~s}$, followed by washing with water for 30s and drying. The Fortify thin layer was applied on the all surfaces of sample and the photoactivation occurred according to the previous group. After, stored at $37^{\circ} \mathrm{C}$ without humidity for $24 \mathrm{~h}$.

\section{Simulation of surface erosion}

After using the respective erosion challenge control methods, the samples surfaces were subdivided into three groups according to the gastric acid erosion simulation frequency [11] $(n=10)$.

- Negative exposure control: this subgroup was immersed in $10 \mathrm{ml}$ of deionized water at $37^{\circ} \mathrm{C}$ and were not submitted to any acid solution during the execution of the cycles of the other subgroups.

- 9 cycles of DES-RE: each complete cycle consists of immersing the all sample surfaces into $10 \mathrm{ml}$ of hydrochloric acid solution (5\% Hall with $\mathrm{pH}=2.2$ ) for $2 \mathrm{~min}$ at room temperature. Afterwards, the specimens were washed with a disposable syringe containing $20 \mathrm{ml}$ of deionized water and immersed for $60 \mathrm{~min}$ in remineralizing solution. [12] The composition included $1.5 \mathrm{mmol} / \mathrm{L} \mathrm{Ca}, 0.9 \mathrm{mmoll} / \mathrm{L} \mathrm{PO}$, $0.15 \mathrm{~mol} / \mathrm{L} \mathrm{KCl}$, and $20 \mathrm{mmol} / \mathrm{L}$ TRIS buffer at $\mathrm{pH}$ 7.0. [11] Between the cycles, the units were stored at relative humidity at $37^{\circ} \mathrm{C}$.

- 18 cycles of DES-RE: the samples of this subgroup were subjected to the double cycle frequency to promote a more aggressive challenge. Each cycle was performed as previously described.

\section{solubility \\ Evaluation of water sorption and}

The water sorption and solubility test were performed based on ISO 4049: 2000. [13] The thickness of the samples was measured in a digital caliper, with an accuracy of $0.01 \mathrm{~mm}$, and these values were used to calculate the volume (V) of each specimen $\left(\mathrm{mm}^{3}\right)$. All weighing was performed on analytical balance (Analytical Plus, Ohaus ${ }^{\circledR}$ Corporation, Florham Park, Switzerland), with precision of one hundredth of a thousandth of a gram.

After 24h the erosive challenge, the samples were placed in a desiccator and transferred to preconditioning at $37^{\circ} \mathrm{C}$. The samples were 
repeatedly weighed at $24 \mathrm{~h}$ intervals until a constant mass $(\mathrm{m} 1)$ (variation of less than 0.2 $\mathrm{mg}$ in a $24 \mathrm{~h}$ period) was obtained. After mass stabilization in $\mathrm{m} 1$, the specimens were stored individually in sealed vials containing $2 \mathrm{ml}$ of deionized water $(\mathrm{pH} 7.2)$ at $37^{\circ} \mathrm{C}$ for seven days. [10] After this storage period, the samples were weighed again (m2). For this, after being removed from the water, the specimens were washed in running water, and the excess water removed with absorbent paper until the water was no longer visualized, and then the weight was noted (m2). The specimens were returned to dry, flasks open and returned to the desiccator at $37^{\circ} \mathrm{C}$ for removal of absorbed water. The sample was weighed daily until a constant mass of water released (m3) was obtained, as previously described.

The water sorption (Ws) and solubility (Sol) in the seven days of water storage were calculated using the following formulas [10]:

$$
\mathrm{Ws}=\frac{\mathrm{M} 2-\mathrm{M} 3}{\mathrm{~V}} \quad \text { Sol }=\frac{\mathrm{M} 1-\mathrm{M} 3}{\mathrm{~V}}
$$

Where $\mathrm{m} 1$ is the mass of the samples in $\mu \mathrm{g}$ before immersion in deionized water, $\mathrm{m} 2$ is the mass of the samples in $\mu \mathrm{g}$ after immersion in deionized water for seven days, $\mathrm{m} 3$ is the mass of the samples in $\mu \mathrm{g}$ after release of water in a desiccator with silica gel and V is the volume of the samples in $\mathrm{mm}^{3}$ [10].

\section{Statistical analysis}

Initially the exploratory analysis of the data was performed to verify the homogeneity of the variances. Also, to determine if the experimental errors had normal distribution (Variance Analysis Parameters). Inferential statistical analysis was performed using 2-way ANOVA and Tukey's test for multiple comparisons. This analysis was done in the statistical program SAS, version 9.1, with significance level of $5 \%$.

\section{RESULTS}

According to the data statistical analysis, no significant interaction between the factors "control method" and "erosive challenge" (water sorption $\mathrm{p}=0.65 /$ solubility $\mathrm{p}=0.61$ ) was observed, indicating independence between them. The main factors were analyzed separately by the Tukey test.

Tables 1 and 2 show the mean and standard deviation of the water sorption and solubility obtained in the experimental groups.

Table 1 - Mean (standard deviation) of the water sorption data in the experimental groups.

\begin{tabular}{|ccccc|}
$\begin{array}{c}\text { Method for } \\
\text { controlling } \\
\text { the erosive } \\
\text { challenge }\end{array}$ & Erosive challenge & \\
\hline & $\begin{array}{c}\text { Negative } \\
\text { Control }\end{array}$ & $\begin{array}{c}\text { 9 DES-RE } \\
\text { cycles }\end{array}$ & $\begin{array}{c}\text { 18 DES-RE } \\
\text { cycles }\end{array}$ & \\
\hline $\begin{array}{c}\text { Negative } \\
\text { Control }\end{array}$ & $57.74(4.66)$ & $58.42(3.95)$ & $62.18(3.48)$ & B \\
\hline $\begin{array}{c}\text { TAF } \\
\text { RMGl Varnish } \\
\text { (ClinproXT) }\end{array}$ & $55.33(6.51)$ & $58.61(6.23)$ & $59.08(4.20)$ & B \\
\hline $\begin{array}{c}\text { Resin Sealant } \\
\text { (Fortify) }\end{array}$ & $60.79(7.36)$ & $70.47(5.79)$ & $68.92(5.64)$ & A \\
\hline & b & $59.37(6.86)$ & $63.60(6.14)$ & B \\
\hline
\end{tabular}

Distinct letters represent statistically significant differences (2-way Anova/Tukey, alfa=5\%). Uppercase letters compare methods of control and lowercase ones compare the erosive challenges.

Table 2 - Mean (standard deviation) of the water solubility data in the experimental groups.

\begin{tabular}{|c|c|c|c|c|}
\hline \multirow{2}{*}{$\begin{array}{l}\text { Method for } \\
\text { controlling } \\
\text { the erosive } \\
\text { challenge }\end{array}$} & \multicolumn{3}{|c|}{ Erosive challenge } & \\
\hline & $\begin{array}{c}\text { Negative } \\
\text { Control }\end{array}$ & $\begin{array}{l}9 \text { DES-RE } \\
\text { cycles }\end{array}$ & $\begin{array}{l}18 \text { DES-RE } \\
\text { cycles }\end{array}$ & \\
\hline $\begin{array}{l}\text { Negative } \\
\text { Control }\end{array}$ & $56.92(4.81)$ & $57.60(3.81)$ & $59.74(4.82)$ & B \\
\hline TAF & $53.95(7.24)$ & $58.56(5.60)$ & $58.33(4.26)$ & B \\
\hline $\begin{array}{c}\text { RMGI Varnish } \\
\text { (Clinpro XT) }\end{array}$ & $67.18(7.90)$ & $69.33(5.89)$ & $66.78(5.21)$ & A \\
\hline \multirow[t]{2}{*}{$\begin{array}{l}\text { Resin Sealant } \\
\text { (Fortify) }\end{array}$} & $58.75(5.61)$ & $58.43(6.80)$ & $62.13(6.01)$ & B \\
\hline & $b$ & $a b$ & $\mathrm{a}$ & \\
\hline
\end{tabular}

Distinct letters represent statistically significant differences (2-way Anova/Tukey, alfa $=5 \%)$. Uppercase letters compare methods of control and lowercase ones compare the erosive challenges. 
Statistical differences between the levels of factor "control method" were observed in both variables $(p<0.001)$. Regardless of the erosive challenge received, the samples protected with RMGI Varnish presented higher averages than the other groups. Statistically different values were also observed among the means of erosive challenges ( $p=0.04)$. According to the data, in all erosion challenge control groups, water sorption and solubility averages after 18 cycles of DES-RE were statistically higher than those of the negative control.

\section{DISCUSSION}

While caries disease has decreased in its incidence over the last decades, non-carious lesions, such as those from dental erosion, have suffered a significant increase in its occurrence. $[12,14]$ It should be noted that, the restorative materials present in the oral cavity are also under the effect of erosive challenges. Therefore, it is important that there is clinical artifice capable of acting to prevent deleterious effects on restorations, avoiding discomfort for the patient and promoting the longevity of the restorative material.

The erosion phenomenon induces loss of substances, surface degradation and reduction of abrasion resistance of restorative materials. [15] In addition, the surface of restorative material is more susceptible to erosive attacks than when compared to dental enamel. [15] Previous studies have shown that when the restorative material, especially the composite resin, is exposed to the erosive challenge, for example there is loss of hardness, greater wear and marginal infiltration. $[15,16]$ When exposed to chemicals substances, the resin matrix of the composite resin can be softened and its constituents can be filtered out of the structure, causing functional and aesthetic damage to the restoration. [17]

The chemical composition of the organic matrix of the restorative material has a direct effect on its degradation. Apparently, the extent and rate of water absorption is dependent on the density of the polymer network and the potential binding of hydrogen and polar interactions. [9]

The composite resin used in this study has, as part of its composition, BISGMA, UDMA and TEGDMA, which are popular monomers present in most of the composite resins commercialized in the current market. After being evaluated in a recent study, it was verified that the structures of these monomers are composed of polymers of different atoms (carbon, oxygen and nitrogen). In addition to the presence of hydrolytically sensitive groups, such as ester, urethane and hydroxyl groups. Besides of does not being considered extremely hydrophilic, those groups are certainly capable of absorbing and losing water easily, to a potentially harmful extent, thus causing the sorption phenomenon and water solubility in the composite resin. [9]

One of the findings of the present investigation reveals that, regardless of surface protection, all specimens had increased water sorption and solubility with exposure to erosive challenges. The sorption phenomenon in composite resins is a controlled diffusion mechanism responsible for causing chemical degradation of the material due to the release of residual monomers and loss of adhesion of the polymer matrix. Already solubility is characterized by the amount of non-reactive monomers that are lost to the medium. Both mechanisms are capable of promoting the degradation of the composite, inducing the weakening of the mechanical properties of the material, formation of microcracks, plasticization of the polymer matrix, as well as the reduction of the wear resistance. [18]

The water solubility of the composite resin is mainly attributed to the lost amount of residual free monomers, additives, fillers and fillers. [19] The amount of monomers that do not react and which are consequently lost is highly dependent on the degree of conversion, that is, the higher the value of the conversion degree, the lower the amount of non-reactive monomers, resulting in a lower solubility. $[18,20,21]$ In the present work, all specimens were submitted to identical 
methods of photoactivation, in an attempt to standardize the number of unreacted species among them.

However, the susceptibility of free monomers to be lost is also related to the hydrophilic and mobility capacity of compounds in general, and those that contain TEGDMA are the most susceptible to leaching, as is the case of the composite resin used in this study. $[22,23]$ However, water in the study in question was less damaging to composite resin than other substances tested, such as ethanol and acidic substances at different concentrations (lactic, propionic and acetic acid). [23]

The particle size of the composite resin may also influence its possible structural modification after erosive events. [24] However, larger particle composites may suffer more from this effect than nanoparticles, as used in this study. In a study that compared changes in microhybrid and nanoparticulate resins after immersion in solutions that simulated two types of wines, it was verified that the nanoparticulate resin presented a less rough and eroded surface in relation to the microhybrid. [24]

Acid cycles simulating surface erosion were characterized by a low $\mathrm{pH}$, around 2.2 , totally critical to the integrity of the composite resin. [11] In the present study, the acid cycles were characterized by specimens that randomly suffered 9 DES-RE cycles or those who received a doubled dose of DES-RE cycles (18) to promote a more aggressive challenge. [12] Therefore, in the current study, it was observed that, independently of the surface protection received, all specimens showed a significant increase in water sorption and solubility after 18 cycles of DES-RE.

The experimental hypothesis tested in the present study was denied since the surface protection method was able to adequately protect the surface of the composite resin, preventing its loss and gain of mass in contact with humidity. Both topical application of fluoride and resin sealant presented similar results to the absence of surface protection at different levels of simulated erosion. However, in the same situations, the resin-modified glass ionomer varnish presented significantly higher values of water sorption and solubility.

Studies demonstrated satisfactory action of $\mathrm{NaF}$ based vehicles in the prevention of dental erosion in vitro. [25,26] On the teeth, $\mathrm{NaF}$ added to the calcium from the saliva leads to the formation of calcium fluoride, which generates a protective barrier, reducing the acid contact with the dental structure. $[25,26]$ However, it was not possible to define whether the fluoride protection layer could also be formed on composite resin surfaces. [27] In addition, fluoride has a short life in the oral environment, as it is easily removed through the action of cheeks, tongue, saliva, chewing and by the usual oral hygiene procedures. [28]

There are evidences that shows a possible damaging effect of fluoride on restorative materials, causing changes in morphological and abrasion resistance. [15] In addition, fluoride can cause depolymerization of the matrix-body constituent interface, causing loss of important constituents of the composite resin. [15] In the present study, this fact can be confirmed, since the topical application of fluoride presented a similar result to the absence of surface protection, in the different levels of simulated erosion.

Similarly, to the TAF, the resin sealant veneer was also not able to alter the water sorption and solubility of the composite resin at different degrees of erosive challenge. This protective material, due to its low viscosity, is able to flow into the dentinal tubules, as a result obtaining part of its mechanical retention and providing depth to the sealant. [27] However, it is not possible to state that the same result occurs on the surface of the restorative material.

In a previous study that tested, the action of different resin sealants. Among them Fortify, on the nanoparticulate composite resin (Filtek Z350) after 30.000 simulated brushing sessions presented no improvement in the rugosity of the composite resin. Fortify Plus had its performance 
reduced when compared to the control group (it did not receive resin sealant protection) after 6 months of brushing, as it allowed a potential loss of load that resulted in a rougher surface. [29]

In relation to the action of the RMGI Varnish, a relevant finding of the present investigation was that in all levels of erosive challenge, presented statistically superior values of water sorption and solubility. Therefore, the loss and mass gain in this protective material exceeded the others. Nevertheless, it was expected to find favorable results when the action of this sealant on the surface of the composite resin, since many studies have proved the efficacy of the product when applied on the dental surface.

The most recent studies evaluating the potential of protection of some materials against enamel demineralization, among them the ionomer varnish obtained the highest mean remineralization potential and better inhibition of dental tissue softening when exposed to acidic challenges. This can be explained by the fact that calcium triphosphate technology has been developed to deliver fluoride, calcium and phosphate continuously and accurately. The calcium triphosphate particles are involved with sodium lauryl sulfate and included in a dental veneer containing $5 \%$ sodium fluoride. During its production process, a protective barrier is created around calcium, allowing it to coexist with fluoride. After applying to the desired surface, in contact with saliva, calcium and fluoride are released. [30] In addition, due to its micromechanical adhesion to the dentin after conditioning with phosphoric acid, a barrier with a greater permanence capacity is formed on the surfaces. [1,31] The efficacy of these fluoride based materials against to the DES-RE depends on the concentration, type of fluoride ion and its release form. The ionomer base materials are more durable, and it still present calcium and phosphate, which are useful supplements in the remineralization process. In addition to the high release of fluoride, derived from the fluoraluminiosilicate glass, present in the sealant composition. $[1,32]$
However, it is important to note that, in all these previous studies, the RMGI Varnish was tested on the dental surface, having experimental conditions different from the present study. In this way, it is not possible to know if the same sealant action process or the results found occur when the varnish is applied on the surface of the composite resin.

In other studies, many compounds containing radiopaque glasses, such as the ionomer varnish in question, have shown great dissolution capacity in water and saline solutions. [9] This potential for deterioration is one of the reasons why it is important to create an organic layer, typically of silane molecules, on the surface of restorative materials in order to protect them from the environment. [33] The same RMGI Varnish presented the lowest hardness value in comparison to the other groups. In protected areas with different covering materials. This fact can be explained by the $35 \%$ phosphoric acid attack prior to the application of the sealant. [34,35] In the dental enamel, the acid attack increases the solubility of the tissue and exposes the enamel prisms. [36] However, the present finding has an important clinical implication. Uncertainty the surface attacked by the acid is not completely covered by the sealant, it will facilitate the penetration of undesirable substances, culminating in the increased incidence of caries disease in the edges of the coating material. [34]

The same, this mechanism is believed to occur on the surface of the composite resin protected with the ionomer varnish in question. Therefore, possibly, this fact explains the result found in the present in vitro study, in which the ionomer varnish presented the highest sorption and water solubility values, when compared to other protection materials.

A challenging factor in the present study was that, many studies show the action of the ionomer varnish on the dental surfaces enamel or the dentin, revealing its potential of protection. However, when it comes to its mechanism of action on the surface of the restorative material, 
in this case, the composite resin, no papers are found that could support its use. In this way, this study exerts a great influence on the clinical behavior of the professional and reveals the need for new studies in the area.

One limitation of the present study is that it can't detect higher sorption of water and solubility found in the groups where the RMGI Varnish was used was due to loss and mass gain of the ionomer varnish or the composite resin. The composite resin used in this study (Filtek Z350 XT) has its composition as TEGDMA, a compound that presents a higher hydrophilic and mobility capacity, thus exerting a great influence on the solubility, that is, it favors the loss of components of the composite resin and not of the covering material. In addition, nanoparticulate resins are able to accumulate a greater amount of water particles along the interfaces of the polymer matrix due to the nonagglomerated particles of $2 \mathrm{~nm}$ of silica present in their composition. [18,20] However, it is concluded that the effect occurred on the surface of cover since the ionomers are less resistant to the conditions of humidity. In a way, this can be considered a positive result regarding the use of the material, since coverings can be redone, and the important thing is that there is no damage to the restorative material. However, given the lack of literature regarding conditions similar to those tested in the present investigation, it is fundamental that more studies be carried out, with complementary variables, and that can determine the real effectiveness of these materials in patients subjected to erosive challenges.

\section{CONCLUSION}

According to the limitations of the present in vitro study, it is possible to conclude that the more aggressive erosive challenge (18 cycles DES-RE) significantly altered the physical properties of the composite resin, increasing water sorption and solubility, thus affecting longevity of the composite resin as restorative material.
Regarding the protection of composite resin surfaces, no control method presented a promising ability to protect the composite resin surface against erosive challenges. This is due to the fact that even the effect of fluoride varnish presented the highest averages for water sorption and solubility, it is not known whether this result occurred on the surface of the covering material or the restorative material.

\section{ACKNOWLEDGMENTS}

Authors thank FAPESB, grant RED 019/2013 and 3M-ESPE for material support for this investigation.

\section{REFERENCES}

1. Zhou SL, Zhou J, Watanabe S, Watanabe K, Wen LY, Xuan K. In vitro study of the effects of fluoride-releasing dental materials on remineralization in an enamel erosion model. J Dent. 2012 Mar;40(3):255-63. doi: 10.1016/j. jdent.2011.12.016. Epub2011 Dec 28.

2. Prati C, Montebugnoli L, Suppa P, Valdre G, Mongiorgi R. Permeability and morphology of dentin after erosion induced by acidic drinks. J Periodontol. 2003 Apr;74(4):428-36.

3. Ranjitkar S, Kaidonis JA, Smales RJ. Gastro esophageal reflux disease and tooth erosion. Int J Dent. 2012;2012:479850. doi: 10.1155/2012/479850. Epub 2011Dec 12.

4. FarahmandF, Sabbaghian M, Ghodousi S, Seddighoraee N, Abbasi M. Gastro esophageal reflux disease and tooth erosion: a cross-sectional observational study. Gut Liver. 2013 May;7(3):278-81. doi: 10.5009/ gnl.2013.7.3.278. Epub2013 Apr 9.

5. BartlettDW, Coward PY. Comparison of the erosive potential of gastric juice and a carbonated drink in vitro. J Oral Rehabil. 2001 Nov;28(11):1045-7.

6. Lussi A, Hellwig E, Ganss C, Jaeggi T. Buonocore Memorial Lecture. Dental erosion. Oper Dent. 2009 May-Jun;34(3):251-62.

7. Soares CG, Carracho HG, Braun AP,Borges GA, Hirakata LM, Spohr AM. Evaluation of bond strength and internal adaptation between the dental cavity and adhesives applied in one and two layers. Oper Dent. 2010 JanFeb;35(1):69-76. doi: 10.2341/09-061-L.

8. WegehauptF, Gries D, Wiegand A, Attin T. Is bovine dentine an appropriate substitute for human dentine in erosion abrasion tests? J Oral Rehabil. 2008 May;35(5):390-4. doi: 10.1111/j.1365-2842.2007.01843.x.

9. Ferracane JL. Hygroscopic and hydrolytic effects in dental polymer networks. Dent Mater. 2006 Mar;22(3):211-22. Epub 2005 Aug 8.

10. Malacarne J, Carvalho RM, Goes MF, Svizero N, Pashley DH, Tay FR, et al. Water sorption/solubility of dental adhesive resins. Dent Mater. 2006 0ct;22(10):973-80. Epub 2006 Jan 6.

11. de Queiroz MMV, Shibasaki PAN, Lima MJP, de Araújo RPC, Foxton RM, Cavalcanti AN. Effect of erosion and methods for its control on the surface roughness of composite resin. Rev Odonto Cienc. 2017;32(2):88-93 
12. Austin RS, Stenhagen KS, Hove LH, Dunne S, Moazzez R, Bartelett DW, et al. A qualitative and quantitative investigation into the effect of fluoride formulations on enamel erosion and erosion-abrasion in vitro. J Dent. 2011 Oct;39(10):648-55. doi: 10.1016/j.jdent.2011.07.006. Epub 2011 Jul 28.

13. ISO-Standards (2000) ISO 4049 Dentistry-Polymer-Based filling, restorative and luting materials Geneve: International Organization for Standardization 18-21.

14. Castilho AGR, Salomão PMA, Buzalaf MAR, Magalhães AC. Protective effect of experimental mouth rinses containing NaF and TiF4 on dentin erosive loss in vitro. J Appl Oral Sci. 2015 0ct;23(5):486-90. doi: 10.1590/1678775720150127.

15. Yu, H, Cheng H, Buchalla W, Wiegand A, Attin T. Topical fluoride application is able reduce acid susceptibility of restorative materials. Dent Mater J. 2012;31(3):433-42. Epub 2012 May 14.

16. Honório HM, Rios D, Francisconi LF, Magalhães AC, Machado MA, Buzalaf MA. Effect of prolonged erosive $\mathrm{pH}$ cycling on different restorative materials. J Oral Rehabil. 2008 Dec;35(12):947-53. doi:10.1111/j.1365-2842.2008.01856.x. Epub 2008 0ct29.

17. Hamouda IM. Effects of Various Beverages on Hardness, Roughness, and Solubility of Esthetic Restorative Materials. J Esthet Restor Dent. 2011 Oct;23(5):315-22. doi: 10.1111/.1708-8240.2011.00453.x. Epub 2011 Jun 22.

18. Goncalves L, Amaral CM, Poskus LT, Guimarães JGA, Silva EM. Degradation of resin composites in a simulated deep cavity. Braz Dent J. 2014 NovDec;25(6):532-7. doi: 10.1590/0103-6440201300089.

19. Van Landuyt KL, Nawrot T, Geebelen B, De Munck J, Snauwaert J, Yoshihara K, etal. How much do resin-based dental materials release? A meta-analytical approach. Dent Mater.2011 Aug;27(8):723-47. doi:10.1016/j. dental.2011.05.001. Epub 2011 Jun 12.

20. Silva EM, Almeida GS, Poskus LT, Guimarães JGA.Relatioship Between the Degree of Conversion, Solubility and Salivary Sorption of a Hybrid and a Nanofilled resin composite: Influence of the Light-activation mode. J Appl Oral Sci. 2008 Mar-Apr;16(2):161-6.

21. Golçalves L, Filho, JDN, Guimarães JGA, Poskus LT, Silva EM. Solubility, Salivary Sorption and Degree of Conversion of Dimethacrylate-Based Polymeric Matrixes. J Biomed Mater Res B Appl Biomater. 2008 May:85(2):320-5.

22. Alshali RZ, Salim NA, Satterthwaite JD, Silikas N. Long-term sorption and solubility of bulk-fill and conventional resin-composites in water and artificial saliva. J Dent. 2015 Dec;43(12):1511-8. doi: 10.1016/j.jdent.2015.10.001 Epub 2015 0ct 9 .

23. Munchow EA, Ferreira ACA, Machado RMM, Ramos TS, Rodrigues-Junior SA, Zanchi CH. Effect of Acidic Solutions on the Surface Degradation of a Micro-Hybrid Composite Resin. Braz Dent J. 2014;25(4):321-6.

24. Tantanuch S, Kukiattrakoon B, Peerasukprasert T, Chanmanee N, Chaisomboonphun P, Rodklai A. Surface roughness and erosion of nanohybrid and nanofilled resin composites after immersion in red and white wine. J Conserv Dent. 2016 Jan-Feb;19(1):51-5. doi: 10.4103/09720707.173199 .
25. Comar LP, Cardoso CA, Charone S, Grizzo LT, Buzalaf MA, Magalhães AC. $\mathrm{TiF}^{4}$ and $\mathrm{NaF}$ varnishes as anti-erosive agents on enamel and dentin erosion progression in vitro. J Appl Oral Sci. 2015 Jan-Feb;23(1):14-8. doi: 10.1590/1678-775720140124.

26. Algarni AA, LippertF, Hara AT. Efficacy of stannous, fluoride and their combination in dentin erosion prevention in vitro. Braz Oral Res. 2015;29. pii: S1806-83242015000100276. doi:10.1590/1807-3107BOR-2015.vol29.0081.

27. Sundaram G, Wilson R, Watson TF, Bartlett DW. Effect of resin coating on dentine compared to repeated topical applications of fluoride mouth wash after an abrasion and erosion wear regime. J Dent. 2007 0ct;35(10):814-8. Epub 2007 Sep 12

28. Cochrane NJ, Shen P, Yuan Y, Reynolds EC. Ion release from calcium and fluoride containing dental varnishes. Aust Dent J. 2014 Mar;59(1):100-5. doi: 10.1111/adj.12144. Epub 2014 Feb 4.

29. Lopes MB, Saquy PC, Moura SK, Wang L, Graciano FMO, Correr Sobrinho L et al. Effect of Different Surface Penetrating Sealants on the Roughness of a Nanofiller Composite Resin. Braz Dent J. 2012;23(6):692-7.

30. Elkassas D, Arafa A. Remineralizing efficacy of different calcium-phosphate and fluoride based delivery vehicles on artificial caries like enamel lesions. J Dent. 2014 Apr;42(4):466-74. do:: 10.1016/j.jdent.2013.12.017. Epub 2014 Jan 9.

31. Sohn S, Yi K, Son HH, Chang J. Caries-preventive Activity of Fluoride-containing Resin-based Desensitizers. Oper Dent. 2012 MayJun;37(3):306-15. doi: 10.2341/11-007-L. Epub 2012 Feb 7.

32. Paschos E, Kleinschrodt T, Clementino-Luedemann T, Huth KC, Hickel R, Kunzelmann KH, Rudzki-Janson I. Effect of different bonding agents on prevention of enamel demineralization around orthodontic brackets. Am J Orthod Dentofacial Orthop. 2009 May;135(5):603-12. doi: 10.1016/J. ajod0.2007.11.028.

33. Venz S, Dickens B. NIR-spectroscopic investigation of water sorption characteristics of dental resins and composites. J Biomed Mater Res. 1991 Oct;25(10):1231-48.

34. Alsayed EZ, Hariril, Nakashima S, Shimada Y, Bakhsh TA, Tagami J, et al. Effects of coating materials on nanoindentation hardness of enamel and adjacent areas. Dent Mater. 2016 Jun;32(6):807-16. doi:10.1016/j. dental.2016.03.023. Epub 2016 Apr 8

35. Kohda N, Lijima M, Brantley WA, Muguruma T, Yuasa T, Nakagaki S, Mizoguchi l. Effects of bonding materials on the mechanical properties of enamel around orthodontic brackets. Angle Orthod. 2012 Mar;82(2):187-95 doi: 10.2319/020411-78.1. Epub 2011 Aug 9.

36. Pashley DH, Tay FR. Aggressiveness of contemporary self- etching adhesives. Part ll: etching effects on unground enamel. Dent Mater.2001 Sep;17(5):430-44.

\section{Andrea Nóbrega Cavalcanti (Corresponding address)}

A Silveira Martins, $\mathrm{n}^{\circ}$ 3386, Cabula. 41150-100, Salvador-Ba Brazil.

+55 71 3257-8200

Date submitted: 2018 Sep 24

andreacavalcanti@yahoo.com.br 